\title{
The Communist past of Albania and the Country in 25 Years of Transition
}

\author{
Dr. Bledar Abdurrahmani
}

University "Aleksandër Moisiu", Durrës, Faculty of Political Science and Law, Departament of Law

\begin{abstract}
Already quarter of a decade after the fall of communism in Albania, the country continues to struggle with an undergoing profound political, economic, social and legal transition period. This long transition challenges the constitutional aspiration of the Albanian people to build a democratic state that is founded on the protection and guarantee of human rights and fundamental freedoms, on building a future of social peace and economic prosperity. Despite a large corpus of constitutional and legal measures undertaken during the transition years to build a state of law based on freedom and human rights, the initiative of the free market, private and public property, they have failed to address adequately the demand for respect of human rights and fundamental freedoms of a category of subjects that during communism suffered the profound violation of these rights, were victims of vicious inhuman acts and unable to benefit from repair as much as possible of the consequences of these violations. This paper aims to make a thorough analysis of the concept of transitional justice, the legal instruments of international law used to address the obligation of ex communist states to take measures for the eradication of the communist past, as a prerequisite for building a functional democracy founded upon social peace and prosperity. The essence of this paper lies in assessing how these instruments are reflected in domestic legislation, the stage they are and the effects they have brought about. The focus of this paper are the factors that have conditioned the separation of Albania from its communist past and the steps needed to be undertaken.
\end{abstract}

Keywords: transitional justice, fundamental rights and freedoms, UN, the Council of Europe, lustration, the communist past. 